\title{
Comparing of Yield and Yield Components of Hybrid Rice (GRH1) in Different Application of Nitrogen Fertilizer
}

\author{
Sahar Yoseftabar ${ }^{1}$, Allahyar Fallah ${ }^{2} \&$ Jahanfar Daneshian ${ }^{3}$ \\ ${ }^{1}$ Young Researchers Club, Iran Islamic Azad University, Sari Branch, Sari, Iran \\ ${ }^{2}$ Rice Research Institute, Amol, Iran \\ ${ }^{3}$ Seed and Plant Improvement Institute, Karaj, Iran \\ Correspondence: Sahar Yoseftabar, Young Reaserchers Club, Iran Islamic Azad University, Sari Branch, Sari, \\ Iran. Tel: 98-911-313-4083. E-mail: sahar_yoseftabar@yahoo.com
}

Received: July 31, 2012 Accepted: August 13, 2012 Online Published: August 22, 2012

doi:10.5539/ijb.v4n4p60 URL: http://dx.doi.org/10.5539/ijb.v4n4p60

\begin{abstract}
A field trial to determine comparing of yield and yield components of hybrid rice (GRH1) in different application of nitrogen fertilizer, comprising of 2 treatments, nitrogen fertilizer at 100,200 and $300 \mathrm{~kg} / \mathrm{ha}$ was main plot and spilt application at 3 levels $\mathrm{T} 1=(1 / 2 \mathrm{basal}-1 / 2 \mathrm{mid}$ tillering $), \mathrm{T} 2=(1 / 3 \mathrm{~b}$ asal $-1 / 3 \mathrm{mid}$ tillering-1/3panicle initation) and $\mathrm{T} 3=(1 / 4 \mathrm{basal}-1 / 4 \mathrm{mid}$ tillering- $1 / 4$ panicle initation- $1 / 4$ flowering $)$ as sub plot. Using randomized complete block design (RCBD) with 3 replications in rice research institute of Iran-departy of mazandaran (amol) in 2006 cropping season. The results showed that yield and yield components increased significantly with nitrogen fertilizer. Interesting in comparison to 100 and $200 \mathrm{~kg} / \mathrm{ha}$ level application of higher $\mathrm{N}$-fertilizer $300 \mathrm{~kg} / \mathrm{ha}$ showed a positive respond to application of high nitrogen on hybrid cultivar. Effect of different split application N-fertilizer was significantly on parameter of above. Study interaction effect of treatments revealed that all the yield and yield parameters increased significantly with an application of 300 $\mathrm{kg} / \mathrm{ha} \mathrm{N}$-fertilizer at 4 stages.
\end{abstract}

Keywords: hybrid rice, nitrogen, spilt application, yield

\section{Introduaction}

Rice is the most important food crop and a major food grain for more than a third of the world population (zhao et al., 2011). Rice production depends on several factors: climate, physical conditions of the soil, soil fertility, water management, sowing date, cultivar, seed rate, weed control, and fertilization, that is, $\mathrm{N}$ is the main nutrient associated with yield (Hirzel et al., 2011). Nitrogen fertilizer is a major essential plant nutrient and key input for in increasing crop yield (Dastan et al., 2012). The synthesis of cellular proteins, amino acids, nucleic acids, purine and pyrimidine nucleotide are dependent upon $\mathrm{N}$. Urea can also be supplied to plants through the foliage,facilitating optimal $\mathrm{N}$ management, which minimizes $\mathrm{N}$ losses to the environment without affecting yield. Most plants absorb foliar applied urea rapidly and hydrolyze the urea in the cytosol. $\mathrm{The} \mathrm{NH}_{3}$ released may be transported into the chloroplast and be assimilated by the chloroplastidic Glnsynthetase. Alternatively, $\mathrm{NH}_{4}{ }^{+}$may be assimilated directly by the cytosolic Glnsynthetase, which has been reported to be limited to the phloem parenchyma cells in leaves (Hasanuzzaman et al., 2009). Time of nitrogen application acts the important role in increasing rice production. Correct timing of nitrogen application is an important aspect of overall nitrogen correct in rice for its efficient utilization (Iqbal et al., 2008). The numerous N-rate and application timing studies have been and continually are conducted on experiment stations and farms to determine N-recommendations for the various cultivars that are grown in the rice- producing states (Walker et al., 2006). Application $\mathrm{N}$ in split as per need of the crop can considerably increase the N-use efficiency of crop and improve the quality and productivity of rice (Asif et al., 2000). Increasing the number of spilt and supplying $\mathrm{N}$ at flowering stage in addition to the early growth phases produced effects similar to that of three equal split (Alagesan \& Babu, 2011). Panicles with allow percentage of sterile flowers permit the application of higher doses of nitrogen and produce better yield (yoshida, 1981). Grain yield and dry matter increased when application of higher dose of nitrogen fertilizer increased (Zhoung \& Huang, 2002).Rate and timing of $\mathrm{N}$ rate are critical for optimum rice grain yield. Nitrogen increases plant height, panicle number, spikelet number and number of filled spikelet per panicle (Doberman \& Fairhurst, 2000). Nitrogen fertilization increased the number of stems and panicles per square 
meter and the total number of spikelets, reflecting on grain productivity. Excessive tillering caused by inadequate token fertilizer application up to panicle nitiation stage is know to increase protein content and possibly grain yield of rice (Alagesan \& Babu, 2011). Nitrogen contributes to carbohydrate accumulation in culmsand leaf sheaths during the preheading stage and in garin during the grain-filling stage by being a component of photosynthesis (Ghanbari, 2011). Rice hybrid often benefit in rough and whole grain rice yield when $\mathrm{N}$ is top-dressed at the panicle emergence (early heading) growth stage (Walker, 2006). Nitrogen fertilization reduced the percentage of fertile tiller; filled spikelet percentage and grain mass (Dastan et al., 2012). Hybrid rice technology aims to increase the yield potential of rice (Chaturvedi, 2005). Research data show that hybrids differ from conventional varieties in response to nitrogen fertilizer. Current hybrids (XL7 and XL8) produce excellent main crop rice yield with only two nitrogen applications - one application just prior to flooding and a second application just prior to or at heading (Turner, 2002). The number of panicles (heads) and the number of grains per panicle are determined by the preflood $\mathrm{N}$ application. Because the yield is determined prior to midseason on currently grown varieties, yield can no longer be recovered with $\mathrm{N}$ applications at joint movement. Also, the new varieties are generally shorter and have stiffer straw, thus, are less susceptible to lodging associated with excessive early $\mathrm{N}$ applications compared to the older varieties (Wilson et al., 1998). So according to split applicaton nitrogen fertilizer on yield an experiment was carried out: Comparing of yield and yield components of hybrid rice (GRH1) in different application of nitrogen fertilizer.

\section{Materials and Methods}

In order to investigate the comparing of yield and yield components of hybrid rice (GRH1) in different application of nitrogen fertilizer, an experimental design in factorial on the basis of completely randomized block design (RCBD) with 3 replicats carried out in rice research institute of Iran-departy of mazandaran (amol) in 2006 cropping season. Nitrogen fertilizer at $\mathrm{N} 1=100, \mathrm{~N} 2=200$ and $\mathrm{N} 3=300 \mathrm{~kg} / \mathrm{ha}$ was main plot and spilt application at 3 levels $\mathrm{T} 1=(1 / 2$ basal- $1 / 2 \mathrm{mid}$ tillering $), \mathrm{T} 2=(1 / 3$ basal $-1 / 3 \mathrm{mid}$ tillaring- $1 / 3$ panicle initation $)$ and $\mathrm{T} 3=(1 / 4 \mathrm{basal}-1 / 4 \mathrm{mid}$ tillering- $1 / 4$ panicle initation- $1 / 4$ flowering $)$ as sub plot. The soil was clay loam and slightly acidic $(\mathrm{pH}=6.91)$ with total $\mathrm{N} 0.13 .1 \%$ and organic matter $(\mathrm{OM}) 29 \%$. Hybrid rice (GRH1) variety was transplanted at spacing plots of $20 \mathrm{~cm} \times 20 \mathrm{~cm}$. Herbicides were employed against different weeds during the course of study. Plots received identical cultural treatments in terms of ploughing, cultivation seed rate, $\mathrm{P}$ and $\mathrm{K}$ fertilizes and disease control, chemical herbicides. The net plot area was harvested and yield components such as Primary branches, Secondary branches, filled and unfilled grain, grain hill ${ }^{-1}$, panicle length and 1000-grain weight and yield were recorded form plant samples. The plot size was kept as $3 \times 4$ meter. The data were analysed following analysis by SAS software. The duncans multiple range tests was used to compare the means at $5 \%$ of significant.

\section{Results and Discussion}

The results showed that yield and yield components increased significantly with nitrogen fertilizer. The analysis of variance showed significant responses of Primary branches, Secondary branches, filled and unfilled grain, total grain, panicle length, 1000-grain weight and yield to $\mathrm{N}$ rate (Table 1).

Table 1. Analysis of variance of nitrogen fertilizer in yield and yield components

\begin{tabular}{|c|c|c|c|c|c|c|c|c|c|}
\hline Treatment & $\mathrm{df}$ & $\begin{array}{l}\text { Panicle } \\
\text { Length }\end{array}$ & $\begin{array}{l}\text { Primary } \\
\text { branches }\end{array}$ & $\begin{array}{l}\text { Secondary } \\
\text { branches }\end{array}$ & $\begin{array}{l}\text { Unfilled } \\
\text { Grain }\end{array}$ & $\begin{array}{l}\text { Filled } \\
\text { Grain }\end{array}$ & $\begin{array}{l}\text { Total } \\
\text { Grain }\end{array}$ & $\begin{array}{l}\text { 1000-gain } \\
\text { Weight }\end{array}$ & Yield \\
\hline $\mathrm{N}^{\mathrm{T}}$ & 2 & $\begin{array}{l}2.032 \\
* *\end{array}$ & $0.001 * *$ & $34.35 *$ & $\begin{array}{l}894.61 \\
* *\end{array}$ & $\begin{array}{l}8.259 \\
* *\end{array}$ & $\begin{array}{l}811.57 \\
* *\end{array}$ & $13.041 * *$ & $\begin{array}{l}595690.78 \\
* *\end{array}$ \\
\hline $\mathrm{T}^{\ddagger}$ & 2 & $\begin{array}{l}4.783 \\
* *\end{array}$ & $0.691 * *$ & $71.56 * *$ & $\begin{array}{l}1539.24 \\
* *\end{array}$ & $\begin{array}{l}728.44 \\
*\end{array}$ & $279.7 *$ & $17.22 * *$ & $\begin{array}{l}16875.44 \\
*\end{array}$ \\
\hline $\mathrm{N} \times \mathrm{T}^{ \pm}$ & 4 & $1.09 * *$ & $\begin{array}{l}0.325 \\
\text { n.s }\end{array}$ & 9.47 n.s & $\begin{array}{l}70.53 \\
* *\end{array}$ & $\begin{array}{l}128.33 \\
* *\end{array}$ & $\begin{array}{l}312.55 \\
* *\end{array}$ & $1.14 *$ & $\begin{array}{l}174413.55 \\
\text { n.s }\end{array}$ \\
\hline$\% \mathrm{C} . \mathrm{V}$ & & 0.89 & 2.509 & 5.565 & 4.05 & 9.511 & 3.96 & 3.311 & 6.36 \\
\hline
\end{tabular}

Ť: Nitrogen fertilizer kg/ha;

†: Split application;

\pm : Interaction effects of nitrogen fertilizer and spilt application;

* and ** respectively significant at $5 \%$ and $1 \%$. 
The effect of different split application $\mathrm{N}$ fertilizer on yield and yield component were significant (Table1). Application of $\mathrm{N}$ fertilizer significantly increased the yield attributes, viz grain/ear, grain weight/ear and 1000-grain weight (Chaturvedi, 2005).

Study interaction effect of treatments revealed that the Primary branches, Secondary branches, filled and unfilled grain, total grain, panicle length and 1000-grain weight and yield increased significantly with the spilt application of nitrogen fertilizer (Table 1). Hussinzade et al. (2011) showed that the effect of nitrogen fertilizer rates on grain yield and number of tiller per plant in $1 \%$ probability level was significantly. Hollena et al. (2008) showed that the production of spikelet per square meter was increased significantly $(p<0.001)$ with nitrogen fertilization.

Nitrogen fertilization increased the number of stem and panicles per square meter and the total number of spikelets, reflecting on grain productivity.excessive tillering caused by inadequate nitrogen fertilization reduced the percentage of fertile tiller, filled spikelet percentage and grain mass (Dastan et al., 2012).

Interesting in comparison to 100 and $200 \mathrm{~kg} / \mathrm{ha}$ level application of higher $\mathrm{N}$-fertilizer $300 \mathrm{~kg} / \mathrm{ha}$ showed a positive respond to application of high nitrogen on hybrid cultivar. Panicle length and Primary branches, Secondary branches and yield increased when application of higher dose of nitrogen fertilizer up to $300 \mathrm{~kg} / \mathrm{ha}$. Increase split application increased these parameters (Table 2).

Table 2. Effects of nitrogen fertilizer level and split application on yield and yield components

\begin{tabular}{|c|c|c|c|c|c|c|c|c|}
\hline treatment & $\begin{array}{l}\text { Panicle } \\
\text { Length }(\mathrm{cm})\end{array}$ & $\begin{array}{l}\text { Primary } \\
\text { branches }\end{array}$ & $\begin{array}{l}\text { Secondary } \\
\text { branches }\end{array}$ & $\begin{array}{l}\text { Unfilled } \\
\text { Grain }\end{array}$ & $\begin{array}{l}\text { Filled } \\
\text { Grain }\end{array}$ & $\begin{array}{l}\text { Total } \\
\text { Grain }\end{array}$ & $\begin{array}{l}\text { 1000-gain } \\
\text { Weight(gr) }\end{array}$ & $\begin{array}{l}\text { Yield } \\
\text { (kg/ha) }\end{array}$ \\
\hline N1 & $27.71 \mathrm{c}$ & $10.65 \mathrm{~b}$ & $43.46 \mathrm{~b}$ & $63.73 \mathrm{a}$ & $126.35 \mathrm{c}$ & $190.311 \mathrm{c}$ & $23.38 \quad \mathrm{~b}$ & 6989.8 \\
\hline N2 & $28.02 \mathrm{~b}$ & $11.06 \mathrm{a}$ & $45.33 \mathrm{ab}$ & $63.06 \mathrm{a}$ & $133.96 \mathrm{~b}$ & $199.35 \mathrm{~b}$ & $23.50 \mathrm{~b}$ & 7690.3 \\
\hline N3 & 28.64 a & $11.17 \mathrm{a}$ & $47.88 \quad \mathrm{a}$ & $46.95 \mathrm{~b}$ & 146.11 a & 209.85 a & $25.52 \mathrm{a}$ & 8611.9 \\
\hline $\mathbf{T 1}$ & $27.28 \mathrm{c}$ & $10.98 \mathrm{~b}$ & $42.34 \mathrm{~b}$ & $72.14 \quad \mathrm{a}$ & $121.078 \mathrm{c}$ & $193.22 \mathrm{~b}$ & $22.86 \mathrm{c}$ & 7702.3 \\
\hline $\mathbf{T} 2$ & $28.46 \quad \mathrm{~b}$ & $11.07 \mathrm{a}$ & $46.74 \quad \mathrm{a}$ & $65.30 \mathrm{~b}$ & $138.77 \quad \mathrm{~b}$ & $204.05 \quad \mathrm{a}$ & $23.94 \mathrm{~b}$ & 7741.6 \\
\hline T3 & $28.63 \mathrm{a}$ & $11.19 \mathrm{a}$ & $47.60 \quad \mathrm{a}$ & $54.31 \mathrm{c}$ & $146.611 \mathrm{a}$ & $200.92 \mathrm{ab}$ & $25.60 \mathrm{a}$ & 7818.1 \\
\hline
\end{tabular}

Means separation in columns followed by the same letter(s) are not significantly different at $\mathrm{P}<0.05$.

The effect of $\mathrm{N}$ fertilizer application on grain yield hill ${ }^{-1}$ was statistically significant (Table 1). The highest grain yield was produced when $300 \mathrm{~kg} / \mathrm{ha} \mathrm{N}$-fertilizer was applied (8611.9 kg) (Table 2). Dastan et al. (2012) reported that maximum grain in the Taromhashemi cultivar was observed for $150 \mathrm{~kg} \cdot \mathrm{ha}^{-1}$ nitrogen application. Hollen et al. (2008) showed that the highest grain yield production was 8.53 ton ha $\mathrm{h}^{-1}$ under maximum nitrogen application at $240 \mathrm{~kg} \mathrm{ha}^{-1}$. The split application $\mathrm{N}$-fertilizer increased the grain yield significantly. The highest grain yield was $7818.1 \mathrm{~kg}$, when $\mathrm{N}$-fertilizer application in 4 stage, 1/4basal-1/4 mid tillering-1/4panicle initation- $1 / 4$ flowering (Table 2). Hollena et al. (2008) the result recommends that it is worthwhile to apply higher rates of nitrogen fertilizer as it was found to improve the straw crude protein while at the same time producing high grain yield. The some of new cultivars produce yields that are comparable and sometimes greater when a single pre-flood application is made as opposed to a two-or three-way spilt of the total applied nitrogen fertilizer (Norman et al., 2000). The panicle number and number of filled spikelets are determined in the reproductive stage (DeDatta, 1981). Nitrogen increases panicle number, spikelet number per panicle and filled spikelets (Dobermann \& Fairhurst, 2000). The some inferior spikelets of hybrid rice start active filling 20-30days after heading, if $\mathrm{C}$ and $\mathrm{N}$ are sufficient in the late grain-filling stage; these spikelets still have a chance to develop into filled grains (Peng et al., 1998). Nitrogen contributes to spikelet production during the early panicle formation stage and contributes to sink size by decreasing the number of degenerated spikelets and increase hull size during the late panicle formation stage (Ghanbari, 2011). The panicle length was $29.83 \mathrm{~cm}$ with the application of $300 \mathrm{~kg} / \mathrm{ha}$ $\mathrm{N}$-fertilizer with 4 split application, and shortest panicle was $27.03 \mathrm{~cm}$ was found in N1T1 (Table 3). Dastan et al. (2012) showed that effect under nitrogen treatment in 5\% probability level and the maximum panicle length in theTaromhashemi cultivar was observed for $100 \mathrm{~kg} \cdot \mathrm{ha}^{-1}$ nitrogen. Asif et al. (2000) stated that highest $\mathrm{N}$ fertilizer with 2 spilt application although increase panicle length, primary and secondary branches, primary and secondary spikelet to a considerable extent but resulted in significant reduction in normal kernels due to higher kernel abnormalities and poor panicle structure development. 
Table 3. Interaction effects of nitrogen fertilizer level and spilt application on yield and yield components

\begin{tabular}{lllllllll}
\hline Treatment & $\begin{array}{l}\text { Panicle } \\
\text { Length }(\mathrm{cm})\end{array}$ & $\begin{array}{l}\text { Primary } \\
\text { branches }\end{array}$ & $\begin{array}{l}\text { Secondary } \\
\text { branches }\end{array}$ & $\begin{array}{l}\text { Unfilled } \\
\text { Grain }\end{array}$ & $\begin{array}{l}\text { Filled } \\
\text { Grain }\end{array}$ & $\begin{array}{l}\text { Total } \\
\text { Grain }\end{array}$ & $\begin{array}{l}1000 \text {-gain } \\
\text { Weight(gr) }\end{array}$ & $\begin{array}{l}\text { Yield } \\
(\mathrm{kg} / \mathrm{ha})\end{array}$ \\
\hline N1T1 & $27.03 \mathrm{ef}$ & $10.70 \mathrm{de}$ & $39.8 \mathrm{c}$ & $78.53 \mathrm{a}$ & $114.03 \mathrm{de}$ & $192.56 \mathrm{~d}$ & $22.11 \mathrm{~d}$ & $7202 \mathrm{bc}$ \\
N1T2 & $27.96 \mathrm{~cd}$ & $10.63 \mathrm{e}$ & $44.63 \mathrm{bc}$ & $67.3 \mathrm{~b}$ & $132.76 \mathrm{c}$ & $200.06 \mathrm{bc}$ & $22.76 \mathrm{~cd}$ & $7020 \mathrm{c}$ \\
N1T3 & $27.73 \mathrm{de}$ & $10.68 \mathrm{de}$ & $45.96 \mathrm{~b}$ & $61.13 \mathrm{bc}$ & $132.2 \mathrm{c}$ & $181.3 \mathrm{e}$ & $24.24 \mathrm{bc}$ & $6447 \mathrm{~d}$ \\
N2T1 & $27.36 \mathrm{f}$ & $11.1 \mathrm{bcd}$ & $44.11 \mathrm{bc}$ & $72.93 \mathrm{ab}$ & $117.5 \mathrm{~d}$ & $190.43 \mathrm{~d}$ & $22.49 \mathrm{~d}$ & $7490 \mathrm{bc}$ \\
N2T2 & $28.7 \mathrm{~b}$ & $11.3 \mathrm{~b}$ & $46.7 \mathrm{~b}$ & $63.5 \mathrm{bc}$ & $138.8 \mathrm{bc}$ & $202.36 \mathrm{bc}$ & $23.41 \mathrm{~cd}$ & $7701 \mathrm{~b}$ \\
N2T3 & $28.3 \mathrm{bc}$ & $10.8 \mathrm{cde}$ & $47.61 \mathrm{ab}$ & $52.76 \mathrm{c}$ & $145.53 \mathrm{~b}$ & $198.36 \mathrm{c}$ & $25.65 \mathrm{ab}$ & $7880 \mathrm{~b}$ \\
N3T1 & $27.36 \mathrm{ef}$ & $11.16 \mathrm{bc}$ & $44.26 \mathrm{~cd}$ & $64.96 \mathrm{~b}$ & $131.7 \mathrm{c}$ & $196.66 \mathrm{~cd}$ & $23.98 \mathrm{~cd}$ & $8595 \mathrm{ab}$ \\
N3T2 & $28.73 \mathrm{~b}$ & $11.1 \mathrm{bcd}$ & $47.5 \mathrm{~b}$ & $65.1 \mathrm{~b}$ & $144.63 \mathrm{~b}$ & $209.73 \mathrm{~b}$ & $25.67 \mathrm{ab}$ & $8443 \mathrm{ab}$ \\
N3T3 & $29.83 \mathrm{a}$ & $12.26 \mathrm{a}$ & $49.8 \mathrm{a}$ & $49.03 \mathrm{c}$ & $162.03 \mathrm{a}$ & $223.16 \mathrm{a}$ & $26.92 \mathrm{a}$ & $8797 \mathrm{a}$ \\
\hline
\end{tabular}

Means separation in columns followed by the same letter(s) are not significantly different at $\mathrm{P} \leq 0.05$.

Grain weight is a genetically controlled trait, which is greatly influenced by environment during the process of grain filling (Chaturvedi, 2004). Maximum of 1000 -grain weight was $26.92 \mathrm{~g}$ obtained at $300 \mathrm{~kg} / \mathrm{ha} \mathrm{N}$-fertilizer at 4spilt application. The minimum of 1000-grain weight was 26.11g that recorded in N1T1 (Table 3). Applying $10-20 \%$ of total chemical $\mathrm{N}$ at heading is improving grain filling and increased final 1000-grain weight in hybrid rice (Peng et al., 1998). But Huossinzade et al. (2011) showed that the nitrogen fertilizer treatments donot showed any significant effect on 1000-grain weight. The analysis of data showed that maximum of unfilled grains per panicle was 73.53 obtained at $100 \mathrm{~kg} / \mathrm{ha} \mathrm{N}$-fertilizer at 2 spilt applications. The minimum of unfilled grains per panicle was 49.03 that recorded in N3T3 (Table 3). Number of filled grains per panicle was 162.3 obtained at $300 \mathrm{~kg} / \mathrm{ha} \mathrm{N}$-fertilizer at 4 spilt applications. The lowest value of this parameter was 114.03 that recorded in N1T1 (Table 3). Alagesan and Babu (2011) found that levels of N and time of application manifested favorable effect on the number of filled grain per panicle during the periods of study large number of filled grain in a panicle was recorded with the application of $160 \mathrm{~kg} \mathrm{Nha}^{-1}$. The filling duration of single spikelet was negatively related to its final grain weight. Application of $\mathrm{N}$ at heading reduced the filling duration of in ferior spikelets and increased their final weight. Increasing $\mathrm{N}$ uptake after flowering to $30 \%$ of total Nuptake delayed leaf senescence and improved grain filling (Jiang \& Cao, 2002). The nitrogen absorbed during the late phase of panicle formation increases the hull size and percentage of filled grains by decreasing the number degenerated spikelet and contributes to grain filling by increasing the number of degenerated spikelet, and contributes to grain filling by increase spikelets, and contributes to grain filling by increase specific leaf wight and $\mathrm{N}$ contents at the panicle initation, formation stage is critical when determining the potential yield (Lee et al., 2011).

Water and nutrient management, even during late grain filling and delayed harvest, was important for increasing the number of filled grain in hybrid rice (zhao et al., 2011).

The increase of nitrogen fertilizer increased number of primary branches when $300 \mathrm{~kg} / \mathrm{ha} \mathrm{N}$-fertilizer was $4 \mathrm{split}$ application. The minimum primary branches was 10.63 that product in N1T2 (Table 3). Asif et al. (2000) stated that nitrogen application techniques had significant effect on the number of panicle bearing tillers $\mathrm{m}^{2}$. The compensatory relationship where the number of panicles and the number of filled spikelets are often inversely related (Fajeria \& Baligar, 2001). Basal $\mathrm{N}$ application increased total sink size, because of increase in both panicle number and spikelet number panicle. Increase sink size often resulted in a decrease in grain-filling percentage (Peng et al., 1998). Panicle number is influenced by the number of tillers that develop during the vegetative stage (De Datta, 1981). The crude protein concentration in the whole straw, leaf and stem fraction was found to increase $(p<0.01)$ with nitrogen fertilizer level (Hollena et al., 2008). Optimum dose of nitrogen fertilization plays vital role in growth and development of rice plant.Its growth is seriously hampered when lower dose of nitrogen is applied which drastically reduces yield. Nitrogen has a positive influence on the production of effective tillers per plant, yield and yield attributes (Hasanuzzaman et al., 2009).

\section{Conclusions}

The results showed that yield and yield components increased significantly with nitrogen fertilizer. Interesting in comparison to 100 and $200 \mathrm{~kg}$ /ha level application of higher $\mathrm{N}$-fertilizer $300 \mathrm{~kg} /$ ha showed a positive respond to 
application of high nitrogen hybrid cultivar. Effect of different split application $\mathrm{N}$-fertilizer were significantly on parameter of above. Study intraction effect of treatments revealed that all the yield and yield parameters increased significantly with an application of $300 \mathrm{~kg} / \mathrm{ha} \mathrm{N}$-fertilizer at 4 stages. Based on the results, it can be concluded that highest grain yield in hybrid rice achieved in $300 \mathrm{~kg} / \mathrm{ha}$ nitrogen treatment which was splitted as $1 / 4$ basal $+1 / 4$ midtillering $+1 / 4$ panicle $+1 / 4$ flowering .

\section{References}

Alagesan, A., \& Babu, R. (2011). Impact of different nitrogen levels and of application on grain yield and yield attributes of wet seeded rice. International Journal of Food, Agricultural and Veterinary science, 1(1), 15.

Asif, M., Aslan, M., Jabar, A., Rafique, k., Babar, M. R., \& Ehsanullah, A. (2000). Panicle structure,kernel quality and yield of fine rice as influenced by NPK rates and split nitrogen application. International Journal of Agricultural and Biology, 1560-8530.

Chaturvedi, I. (2005). Effect of nitrogen fertilizers on growth, yield and quality of hybrid rice (Oryza sativa L.). Journal of Central European Agricultural, 6(4), 611-618.

Dastan, S., Siavoshi, M., Zakavi, D., Ghanbaria-malidarreh, A., Yadi, R., GhorbanniaDelavar, E., \& Nasiri, A. R. (2012). Applicatio-N of nitrogen and silicon rates on morphological and chemical lodging related characteristics in rice (Oryza sativa L.) north of Iran. Journal of Agricultural Science, 4(6).

DeDatta, S. K. (1981). Principles and practices of rice production. Johan Wiley and Sons, New York.

Doberman, A., \& Fairhurst, T. (2000). Rice: Nutrient disorders and nutrient management. IRRI, Philippines, PPI, USA., and PPIC, Canada.

Fajeria, N. K., \& Baligar, V. C. (2001). Lowland rise response to nitrogen fertilization.Commun. Soil Science.Plant Anal, 32(9\&10), 1405-1333.

Ghanbari-Malidarreh, A. (2011). Silicon application and nitrogen on yield and yield components in rice (Oryza sativa L.), in two irrigation systems. World Academy of Science, Engineering and Technology, 74.

Hasanuzzaman, M., Nahar, K., Alam, M. M., Hossain, M. Z., \& Islam, M. R. (2009). Response of transplanted rice to different application methods of urea fertilizer. International Journal of Sustainable Agricultural, 1(1), 01-05.

Hirzel, J., Pedreros, A., \& Cordero, K. (2011). Effect of nitrogen rates and spilt nitrogen fertilization on grin yield and its components in flooed rice.Chilean Journal of Agricultural Research, 71(3).

Hollena, N., Ridzwan, A. H., \& Mohd, F. R. (2008). Effect of nitrogen fertilization management practice on the yield and straw nutritional quality of commircial rice varieties. Malaysian Journal of Mathematical Sciences 2(2), 61-71.

Hussinzade, A., Azarpour, E., \& Ziaeidoustan, H. (2011). Mnagmen-t of cutting height and nitrogen fertilizer rates on grain yield and several attributes of ratoon rice (Oryza sativa L.) in Iran. World Applied Science Journal, 15(8), 1089-1094.

Iqbal, sh, Ahmad, A., Hussin, A., Anjamali, M., Khaliq, T., \& Wajid, A. (2008). Influence of transplanting data and nitrogen management on productivity of paddy cultivars under variable environments. Friends Science Publisher.

Jiang, L. G., \& Cao, W. X. (2002). Physiological mechanism and approaches for efficient nitrogen utilization in rice. Chinese Journal Rice Science, 16(3), 261-264.

Lee, Y. J, Yang, C. M, Chang, K. W., \& Shen, Y. (2011). Effect of nitrogen status on leaf anatomy, chlorophyll content and canopy reflectance of paddy rice. Botanical Studies, 52, 295-303.

Norman, R. J, Wilson, Jr., C. E., Slaton, N. A., Moldenhauer, K. A. K., Boothe, D. L., Clark, S. D., \& Cox, A. D. (2000). Grain yield response of new rice cultivars. P. 267-271. In R. J. Norman and C. A. Beyrouty (ed.) Arkansas Rice Research Studies, Ark. Agric. Exp. tn. Res. Ser, 476.

Peng, S., Yang, J., Garcia, F. V., Laza, R. C., Visperas, R. M., Sanico, A. L., Chavez, A. Q., \& Virmani, S. S. (1998). Physiology-based crop management for yield maximization of hybrid rice. International Rice Research Institute, p. 157-176.

Turner, F. (2002). Screening Public and Private Rice Varieties for Main and Ratoon Crop Yield and Quality in Texas. Texas Rice Special Section Highlighting Research.

Walker, T. W. (2006). Rice grain yield response to nitrogen fertilization for newly released cultivars and hybrids. 
Mississippi Agricultural and Forestry Experiment Station, 23(20).

Wilson, C. E., Bollich, P. K., \& Norman, R. J. (1998). Nitrogen application timing effects on nitrogen efficiency of dry-seeded rice. Soil Sci. Soc. Am. J., 62, 959-964.

Yoshida, S. (1981). Fundamentals of rice crop science. Los banos (Philippines), International Rice Research Institute, p. 269.

Zhao, L., Wu, L., Wu, M., \& Li, Y. (2011). Nutrient uptake and water use efficiency as affected by modified rice cultivation methods with irrigation. Paddy Water environ, 9, 25-32.

Zhoung, H. A., \& Huang, D. (2002). Grain yield, dry matter production and nitrogen use efficiency as affected by fertilizer application in irrigated rice in Guangadong, south China, International Rice congress. 